\title{
Community forestry frameworks in sub-Saharan Africa and the impact on sustainable development
}

\author{
Lalisa A. Duguma ${ }^{1}$, Joanes Atela $^{2}$, Alemayehu N. Ayana $^{3}$, Dieudonne Alemagi $^{4}$, Mathew Mpanda $^{5}$, Moses Nyago $^{6}$, Peter A. Minang $^{2}$ \\ ${ }^{1}, \underline{\text { Judith M. Nzyoka }}^{1}, \underline{\text { Divine Foundjem-Tita }}^{7}$ and Cécile Ngo Ntamag-Ndjebet ${ }^{8}$
}

\begin{abstract}
Community based forest management (CBFM) has been implemented in Africa since the 1980s. Three main objectives, which are currently part of the sustainable development goals (SDGs), underlie the formation of CBFM. They are (1) enhancing community engagement in forest management, (2) reducing rural poverty, and (3) promoting forest resources conservation. We examine CBFM frameworks in sub-Saharan Africa (SSA) and CBFM schemes' contribution to selected sustainable development goals relevant to the forestry sector. Five SSA countries, Ethiopia, Kenya, Cameroon, Uganda, and Tanzania were chosen for the study because of their long-term engagement in CBFM. The analysis was based on desk review of literature from Web of Science!, Scopus, and Google Scholar!, and interviews with individuals representing institutions leading CBFM implementation in the countries selected. We found countries were strong in devising policy and legal provisions and articulating formalities for establishing CBFM. Major weaknesses were observed in monitoring CBFM performance, benefit sharing, and product management. The analysis of CBFM schemes' contribution to SDGs was largely positive, though with several cases of no considerable impact and few reports of negative impacts. The contributions of CBFM schemes to SDGs was constrained by weaknesses in the CBFM frameworks. Enhancing CBFM schemes contribution to SDGs requires addressing the major weaknesses observed in the CBFM frameworks.
\end{abstract}

Key Words: Africa; community based forest management; forestry; implementation; sustainable development goals

\section{INTRODUCTION}

Local communities play a crucial role in influencing forest management because of their needs for land, wood for energy and construction, and other nontimber forest products (NTFPs). Several scholars and practitioners (e.g., Agrawal and Ribot 1999, Ribot 1999, 2003, Larson 2003, 2005, Blomley 2013), therefore, argue that engaging local actors is a crucial step toward enhancing contribution of resources to community development and at the same time improving resource management through the participation of local communities. This stance tends to contrast with the centralized (government-led) schemes that are largely rated as having failed to ensure proper management of natural resources through the protectionist model. For instance, Enters and Anderson (1999) argued that, contrary to the objective of enhancing conservation, some protected areas experienced loss of biodiversity mainly because there lacked genuine engagement of local communities.

In the 1990s, with support from the World Bank and the International Monetary Fund, the application of the decentralized resource management models started (Anderson 2000, Olowu 2001, Ndegwa 2002, DeGrassi 2003, Sarin et al. 2003, Larson 2005). The World Bank emphasized the need for decentralized resource management for sub-Saharan African countries to foster rapid social and economic development. Community based forest management (CBFM) was among the measures proposed for the forestry sector. It refers to any forest management scheme with a certain degree of participation by local communities under the decentralized forest management model. Local communities living in rural areas are largely dependent on forest goods and services for their livelihood and so allowing them to manage and utilize forests sustainably could reduce forest loss and contribute to local development targets.

Community based forest management was lauded as a strategy to accommodate the voices and needs of local communities living in and around forests (Agrawal and Gibson 1999). Numerous scholars (e.g., Kellert et al 2000, Bwalya 2002, Roe et al. 2009, Ayana et al. 2013, 2017) argued that CBFM might help to amend limitations of the centralized resource management models and could also be a mechanism to address drivers of deforestation emanating from within the communities, thus complementing measures to reduce illegal logging (Roe et al. 2009) at the national level and curbing illegal timber trade at the global level. In this vein, many scholars (e.g., Klooster and Masera 2000, Smith and Scherr 2002) argued that CBFM could generate substantial social and economic benefits and contribute to sustainable development.

Community based forest management also emerged as among the things needed for local governments and communities to have power and authority to manage forest resources. This seemed to hasten economic development, administrative efficiency, and improved natural resources management (Ribot 1999, Anderson 2000, Larson 2003). Larson (2005) argued that rather than correcting the wrongs of limiting local communities' rights to resources, decentralization is often prioritized as a way of enhancing operational efficiency (i.e., reducing costs) and increasing revenues of forest departments. Despite supporting this forest management model, many countries are a bit

\footnotetext{
${ }^{1}$ World Agroforestry Centre, Nairobi, Kenya, ${ }^{2}$ African Centre for Technology Studies (ACTS), ICIPE, Duduvile Campus, Kasarani, Nairobi, Kenya, ${ }^{3}$ Ethiopian Environment and Forest Research Institute, Addis Ababa, Ethiopia, ${ }^{4}$ FOKABS INC., ${ }^{5}$ Delegation of the European Union to Tanzania, Dar es Salaam, Tanzania, ${ }^{6}$ University of Florida, School of Forestry Resources and Conservation, Gainesville, Florida, ${ }^{7}$ World Agroforestry Centre, West and Central Africa Region, Yaoundé, Cameroon, ${ }^{8}$ Cameroon Ecology (Cam-Eco), Edéa, Cameroon
} 
Table 1. The community based forest management (CBFM) framework attributes and their descriptors.

\begin{tabular}{ll}
\hline \hline CBFM framework attributes & Detailed elements of the CBFM framework attributes \\
\hline Policy and legal provisions & Legislative provisions or entitlements \\
& Specifications of allowable forest area per CBFM \\
& Tenure conditions and formalities \\
& Exploitation rights \\
& Mechanisms for delivering technical support to CBFM \\
& Taxation conditions for forest products \\
& Incentives and or disincentives \\
Formalities for establishing community forests $(\mathrm{CFs})$ & Legal requirements for establishing CBFM \\
& Defined procedures for establishing CBFM, e.g., necessity of public consultation, the \\
& institutionalization procedures, etc. \\
& Necessary documentation for establishing CBFM \\
& Nature of the forest management agreements \\
& Approval procedures for the establishment of CBFMs \\
Benefit sharing frameworks & Explicitness of community benefits \\
Monitoring and reporting requirements & Procedures for benefit sharing \\
& Indicators or parameters to be monitored \\
Product management & Reporting procedure and protocol \\
& Activities allowed under CBFM \\
& Marketing formality and market linkages \\
\hline
\end{tabular}

The authors compiled this table using pieces of information from previous works such as Blomley and Ramadhani (2006), Minang et al. (2007a, $b$ ), Alemagi (2010), Beauchamp and Ingram (2011), and Robinson and Lokina (2011).

conservative in widely popularizing the mechanism, for instance, by limiting the forest area designated for this scheme. In Cameroon, for example, CBFM is limited to secondary forests (nonpermanent forests). Under the current forest zoning plan, community forest schemes are allocated only $2 \%$ of the total forest estate (Movuh 2013).

Among the usual challenges of such community-based interventions is the free-riders problem because all the community members may not have equal capacity, interest, and access in managing resources. Communities with weak social capital may also not be that effective in reaching a collective agreement for a collective action required for effective resources management.

Despite the skepticism and concerns, CBFM schemes are being operationalized in many countries. However, after two decades of efforts to devolve management of forest resources to local communities in Africa, still, the guiding frameworks for the implementation of the CBFM schemes are not that explicit and were not properly examined. Moreover, there is limited information regarding the contributions of CBFM schemes to sustainable development goals (SDGs) in the context of subSaharan Africa (SSA). Our aim is: (1) to examine frameworks that guide the design and implementation of CBFM schemes in selected sub-Saharan Africa countries and (2) to assess the contributions of CBFM schemes to relevant SDGs in the SSA context. Five countries were chosen for this study: Ethiopia, Kenya, Uganda, Tanzania, and Cameroon. The long-term experience these countries have had in implementing CBFM schemes was the main selection criteria.

\section{METHODS}

\section{Approach to examine the community based forest management (CBFM) frameworks}

To assess the CBFM frameworks in the case study countries, we chose five broad framework attributes, each of which has its own specific aspects. The broad framework attributes were: (1) policy and legal provisions, (2) formalities for establishment of CBFMs, (3) benefit sharing mechanism, (4) monitoring and reporting requirements, and (5) products management. The attributes were collated from previous works that dealt with CBFM schemes, such as Blomley and Ramadhani (2006), Minang et al. (2007a, b), Alemagi (2010), Beauchamp and Ingram (2011), and Robinson and Lokina (2011). The corresponding details for each framework attribute was obtained by extracting relevant information from published and unpublished official reports and legislative documents. We also obtained additional information through key informant interviews with technical experts representing key institutions working on CBFM issues in the five countries (Table 1).

\section{The review process for assessing community based forest} management (CBFM) impacts

Community based forest managements were designed to deliver multiple benefits. Sustainable development goals, in its localized version, could capture these potentially diverse benefits generated from CBFM schemes. The following five SDGs were used for the impact analysis because of their specific relevance to the objectives of CBFMs: Goal 1, poverty reduction; Goal 2, food security; Goal 3, well-being; Goal 13, climate change; and Goal 15 , forest and biodiversity conservation. Sustainable development goals were chosen for the impact analysis for two main reasons: (1) they are standardized, globally accepted monitoring protocols for assessing development progresses at the country level; and (2) numerous elements of the SDGs were already targets of development ambitions for the case study countries.

The analysis of CBFM contributions to SDG was solely based on existing literature, mostly from the selected five countries. We focused on peer-reviewed articles screened from the Web of Science $^{\mathrm{TM}}$ and Scopus literature databases. Some relevant publications from Google Scholar ${ }^{\mathrm{TM}}$ were also added. The 
Fig. 1. Different forest management models and the position of various community based forest management (CBFM) schemes. The arrows indicate the direction along which the attribute continues to increase. Note participatory forest management captures both the joint management and community management.

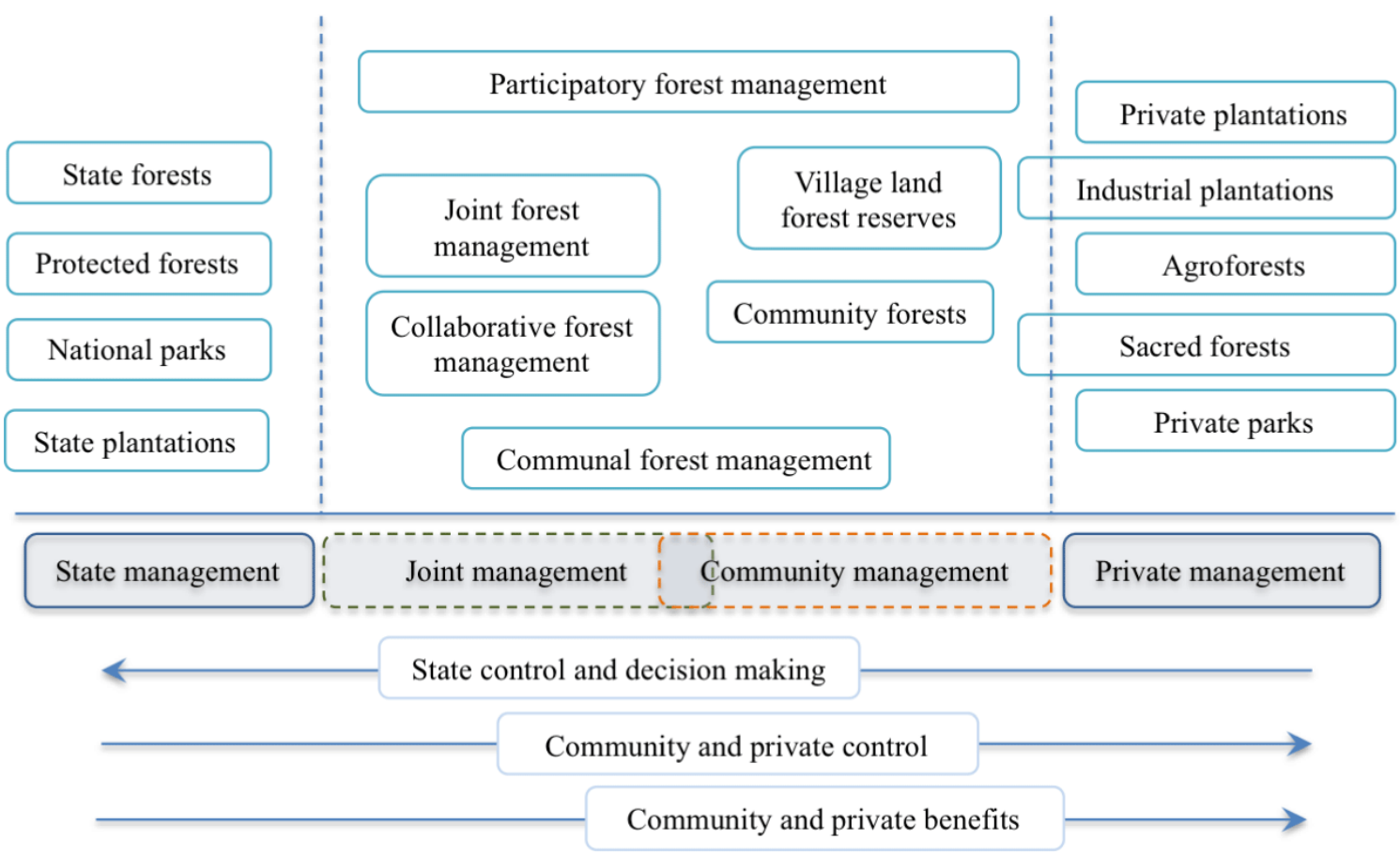

following criteria were used to select the publications: (1) it had to be published after 2000; (2) the publication had to emphasize the impacts of CBFM schemes in a specific African country, preferably any of the five selected; and (3) it had to have empirical evidence revealing impacts, hence not a review. In each publication, we looked for specific evidences relating to the SDGs. In total, we had 44 publications that were highly relevant to the objectives of this study.

The method we adopted in selecting review publications also had its own limitations. First, we only considered publications written in the English language. Second, the search databases were limited to three: Web of Science ${ }^{\mathrm{TM}}$, Scopus, and Google Scholar ${ }^{\mathrm{TM}}$. For these reasons, there is a possibility that some important publications were not included in the analysis.

\section{FINDINGS}

The context and state of community based forest management (CBFM) schemes in the case study countries

Figure 1 illustrates the different forest management models that exist in the case study countries. It is important to note wide diversity of CBFM schemes practiced in the different countries along gradients of decision-making power, control over resources, and benefit accrual. The following is characterization of the CBFM schemes in the different countries:

- In Ethiopia: participatory forest management (PFM) and collaborative forest management (CFM);

- In Kenya: participatory forest management (PFM), community forest (CF), and collaborative forest management (CFM);
- In Tanzania: village land forest reserve (VLFR; a forest managed by the village government and its people in accordance with Village Land Act 1999), joint forest management (JFM), and community forest reserve (CFR);

- In Cameroon: community forests (CF);

- In Uganda: collaborative forest management (CFM) and communal forest management.

The similarity among these typologies is the engagement of local communities as key stakeholders in managing forests.

Though some countries are very specific on the types of CBFMs they are implementing in their countries (e.g., Tanzania), in some there is some generalization. This generalization particularly refers to the PFM concept. In Kenyan, PFM refers to "a forest management approach that deliberately involves the forest adjacent communities and other stakeholders in forest management within a framework that contributes to community's livelihoods" (Kenya Forest Service 2015). In Ethiopia, PFM is used as a strategy to engage local communities to achieve a sustainable forest management objective while also generating livelihood benefits (Tadesse and Teketay 2017). Participatory forest management, however, can take on different forms depending on the level at which local communities are engaged. For instance, if the power over resources is almost equally shared between the state body and the community, it can qualify as CFM (in Ethiopia and Kenya) or JFM (in Tanzania). If the community is the one with the strong decision-making power over the forest, it is more of a CF. Such explicit disaggregation of PFM was observed in Tanzania only when PFM was implemented in two forms: CBFM and JFM. The Tanzania Forest Act supports PFM 
Table 2. The current state of community based forest management (CBFM) schemes and the associated challenges.

\begin{tabular}{|c|c|c|c|}
\hline Country & State of CBFM implementation & $\begin{array}{l}\text { Fundamental reasons for adopting CBFM } \\
\text { schemes }\end{array}$ & $\begin{array}{l}\text { Main challenges CBFM schemes currently } \\
\text { face }\end{array}$ \\
\hline \multirow[t]{3}{*}{ Tanzania } & $\begin{array}{l}409 \text { declared village land forest reserves, of } \\
\text { which } 71 \text { are already gazetted (URT 2011) }\end{array}$ & $\begin{array}{l}\text { Failure of state management of forest } \\
\text { resources and the successes recorded in } \\
\text { community managed forests }\end{array}$ & Very limited financial capacity \\
\hline & & $\begin{array}{l}\text { Enhance the ownership of forests by } \\
\text { communities }\end{array}$ & $\begin{array}{l}\text { Poor technical know-how of managing } \\
\text { forests in a sustainable way }\end{array}$ \\
\hline & & & $\begin{array}{l}\text { Livestock encroachment in village land } \\
\text { forest reserve }\end{array}$ \\
\hline \multirow[t]{3}{*}{ Kenya } & $\begin{array}{l}\text { Approximately } 100 \text { community forest } \\
\text { associations exist currently (Koech et al. } \\
\text { 2009) }\end{array}$ & $\begin{array}{l}\text { Reduce deforestation emanating from } \\
\text { local livelihood needs }\end{array}$ & $\begin{array}{l}\text { Most CBFM schemes lack representation } \\
\text { in national policy decisions }\end{array}$ \\
\hline & & $\begin{array}{l}\text { Create mechanisms of incentivizing } \\
\text { communities to manage forests }\end{array}$ & $\begin{array}{l}\text { Poor financial and technical capacity to } \\
\text { promote CBFMs }\end{array}$ \\
\hline & & & Limited logistic support \\
\hline \multirow[t]{3}{*}{ Ethiopia } & $\begin{array}{l}\text { One million ha of participatory forest } \\
\text { management, } 3 \text { million ha area closures } \\
\text { (MEFCC 2017) }\end{array}$ & Reduce the extent of deforestation & $\begin{array}{l}\text { Limited internalization of CBFM by local } \\
\text { communities }\end{array}$ \\
\hline & & $\begin{array}{l}\text { Engage the community in managing and } \\
\text { protecting the forests }\end{array}$ & $\begin{array}{l}\text { Strong dependency on NGO for financial } \\
\text { and technical support }\end{array}$ \\
\hline & & & Limited CBFM success stories \\
\hline \multirow[t]{5}{*}{ Cameroon } & $\begin{array}{l}\text { About } 375 \text { community forests covering } \\
\text { total area of } 1.3 \text { million ha (Minang et al. } \\
\text { 2018) }\end{array}$ & Reduce deforestation & Poor financial capacity \\
\hline & & $\begin{array}{l}\text { Generate livelihood benefits for the local } \\
\text { communities }\end{array}$ & Limited technical capacity \\
\hline & & $\begin{array}{l}\text { Engage communities in managing their } \\
\text { own resources }\end{array}$ & Poor institutional support \\
\hline & & & $\begin{array}{l}\text { Only secondary forests are permitted for } \\
\text { community forests }\end{array}$ \\
\hline & & & $\begin{array}{l}\text { Lengthy approval processes for CBFM } \\
\text { permits }\end{array}$ \\
\hline \multirow[t]{5}{*}{ Uganda } & $\begin{array}{l}\text { About } 49 \text { CBFMs being implemented } \\
\text { (MWE 2016) }\end{array}$ & $\begin{array}{l}\text { Failure of command-and-control forest } \\
\text { management }\end{array}$ & Limited funding options \\
\hline & & $\begin{array}{l}\text { Enhance community engagement in forest } \\
\text { management }\end{array}$ & $\begin{array}{l}\text { Lack of transparent leadership and benefit } \\
\text { sharing guidelines }\end{array}$ \\
\hline & & $\begin{array}{l}\text { Enhance forest contributions to } \\
\text { community needs }\end{array}$ & Lengthy administrative procedures \\
\hline & & Compliance to international conventions & $\begin{array}{l}\text { Lack of empowering local institutional } \\
\text { frameworks }\end{array}$ \\
\hline & & & $\begin{array}{l}\text { CBFMs often assigned low quality or } \\
\text { degraded forests. }\end{array}$ \\
\hline
\end{tabular}

through promotion of CBFM practices such as VLFR, community forest reserves, and private forests (forests managed by individuals; Blomley and Ramadhani 2006). Nonetheless, countries like Kenya and Ethiopia still use PFM as a single management model despite its wide context that warrants disaggregation to avoid confusion. This disaggregation should lead to better explicitness to understand how much of the managing power is transferred to the community. Ribot et al. (2010) emphasized the need for clarity on such conceptual confusions.

The primary goals of adopting CBFM schemes in the study countries, at least as mentioned in the policy and strategic documents, were: (1) reducing deforestation by transferring management rights to local communities and or by sharing management rights with local communities, and (2) developing pathways of benefiting local communities with the resources located in their proximity. This emphasizes generating income and other livelihood benefits from timber and NTFPs by granting communities access to the resources. Biodiversity conservation is one of the cobenefits highlighted but often not given strong emphasis in CBFM schemes. Nonetheless, the primary objectives of the CBFM schemes are not always the same. Table 2 describes the current state of CBFM schemes in the study countries. It also presents the main reasons for adopting CBFM schemes and the challenges associated with the scheme.

\section{Examining community based forest management (CBFM) framework attributes}

Policy and legal provisions in support of community based forest management schemes

All the study countries had policy and legal frameworks that clearly stipulated supporting the implementation of CBFM 
schemes except in Ethiopia in which there is still an ongoing revision on the draft policy that explicitly includes CBFM. The following are the relevant policy instruments that are concerned with CBFM in each of the countries:

- In Tanzania: Forest Policy of 1998, the Forest Act 2002, Forest Regulations 2004, the Local Government Act 1982, and the Village Land Act 1999;

- In Kenya: Kenya Forestry Master Plan 1995-2020, and Forests Act 2005;

- In Ethiopia: Development, Conservation and Utilization of Wildlife Proclamation (541/2007);

- In Uganda: the Uganda Forest Policy 2001, and The National Forestry and Tree Planting Act 2003;

- In Cameroon: the Forestry, Wildlife and Fisheries Regulation Law 94/01 of 1994 of Cameroon (Republic of Cameroon 1994).

Within the policy and legal provisions attribute, there is a strong need for all the countries to: (1) emphasize the delivery of technical supports to CBFM schemes, (2) formalize the forest area to be managed and used by communities, and (3) frame the incentives and disincentives for better forest management. These three were found to be the least explicitly articulated elements within the policy and legal provision attributes.

In all the countries, local forestry experts had to provide the requisite technical support. These designates, however, are severely resource constrained and often understaffed. Hence, they are not capable of fulfilling the technical support needs of the communities. That is why in the study countries there is a significant engagement of the NGOs in providing the necessary technical and material support for the CBFM schemes.

In Uganda, Ethiopia, and Kenya, forest area limit for CBFM schemes are not specified. In Cameroon, by law, community forests must not exceed 5000 ha and $2 \%$ of the total national forest area when aggregated at a national level. In Tanzania, for a VLFR to be declared and recognized by the responsible ministry, it has to be at least five hectares but there is no specific maximum area limit. For instance, the Angai forest currently managed as a CBFM scheme was estimated to be 139,420 ha (Scheba and Mustalahti 2015).

The tenure conditions and formalities associated with CBFM schemes varied and were found to be quite complex. In Ethiopia, currently, the government is the de facto owner of forests and forestlands. Communities are only entitled to user (access) rights in as much as forest management is concerned. All land, including forestlands, belong to the state and the government can claim the land for any purpose at any time. Thus, there is uncertainty regarding the sustainability of the scheme. In Uganda, despite giving communities rights of management, the management, forests, and forestlands are owned by the government. The situation in Cameroon is very similar to that of Uganda. Communities periodically enter into an agreement (usually for 25 years) with the government agency mandated to oversee forestry activities. In Kenya, despite the law recognizing communal ownership of land resources, there is no clarity on whether communities can own the forestlands they manage. However, in some cases, there is a move to legally transfer communal forestland ownership through local governance structures such as village elders or community. Tanzania exclusively recognizes the rights of communities and villages to forest areas in their village. Tanzania is the only country with exclusive rights granted to the local communities managing the forests.

In all the countries except Tanzania, the details and specifics on incentives and disincentives associated with CBFM schemes were less explicit and weak. The CBFM schemes, in many cases, relied on financial incentives from NGOs and other donor agencies. For example, in Ethiopia, CBFM schemes were so dependent on NGOs that some may not even have any (technical and financial) capability to operate effectively on their own. The situations in Uganda and Kenya (Koech et al. 2009) are quite similar to that of Ethiopia. However, in Tanzania there are three major provisions for communities managing forests (Blomley and Ramadhani 2006): (1) waiving of state royalties on forest products; (2) exemption from local government taxes; and (3) exemption from the reserved tree species list, which allows the villagers to make decisions on the harvesting of commercially important or endangered tree species. Any fines paid for trespassing or illegally using forests are also used by the local community. In Kenya, the situation has largely degenerated into projectization of forestry resources resulting in communities associating specific forest areas supported by projects to clans and individual members working with these projects. In all the countries, commercial uses of forests were subjected to taxation as deemed appropriate by the central government and/or local authorities.

\section{Formalities for establishing community based forest} management (CBFM) schemes

In Cameroon, Kenya, Uganda, and Ethiopia, elite capture issues are very frequent (Mogoi et al. 2012, Oyono et al. 2012, Gelo et al. 2013). In all the studied countries, there is a strong emphasis on the need for public consultation and participation during the design and implementation of CBFM schemes. In Ethiopia, for example, there is evidence that most PFM schemes favor the rich households therefore introducing inequality in how they benefit the participants (Gelo et al 2016). In all the case study countries, there is a clearly articulated management agreement protocol for engaging in CBFM schemes. However, the level of details required for the management agreements varied by country. In Cameroon, for instance, the process of developing management agreements and getting it approved by the responsible government agency (i.e., Cameroon Ministry of Forests and Wildlife) requires a diligent and (relatively) in-depth technical assessment. After the assessments, once approved, the management agreements are less flexible except the revisions to be done every five years. In Tanzania, because villages are granted exclusive rights over forests and forestlands, the management agreements are quite flexible, and most management decisions are made at the local level, i.e., between the village communities willing to manage the forest and the district authorities. Most of the countries clearly stated the legal requirements for an entity or community to manage forests. In most cases, the communities should already be registered officially as legally recognized bodies/entities as a condition for them to be granted forest management rights. Tanzania could be considered an outlier in this regard because the village 
communities that manage the village forestlands may not necessarily need to be recognized as a managing entity because the forest is under their jurisdiction. There is a general weakness in other formalities such as procedures for establishing CBFM schemes, the nature of documentation required, and clarity of the approving authorities.

\section{Benefit sharing}

The specifications available on benefit sharing were found to be very weak in all the countries. There is no country that explicitly describes requirements and procedures for equitable and fair benefit sharing among participating members. When conflicts on benefit sharing emerge, local bylaws, elders mediation, or formal legal procedures are used as complements to address the issues. The local bylaws are often local arrangements between members of the community and are used to resolve issues between members or groups (Yami et al. 2013) that feel they are disadvantaged in how they are rewarded. This method of conflict resolution is also accompanied by local leaders, chiefs, and elders who serve as mediators. Formal procedures of conflict resolution usually happen when conflict is between the community and government bodies or local administrations. This resolution mechanism also applies if the conflict between individuals or groups of communities is not resolved using the local (traditional) means. Koech et al. (2009), in the Kenyan context, suggested conflict resolution should be one of the key roles that communities need to be trained in.

In all the countries, cases of elite capture were reported even among community members engaged in forest management. The problem was more rampant in countries such as Cameroon (Beauchamp and Ingram 2011, Ezzine de Blas et al. 2011). The problem of elite capture is often caused by elites who are either educated, or wealthy families, politically connected local officials, or even local chiefs or leaders. In CBFM schemes in which extractable wood products such as timber or firewood, are involved, the interests of such elites may even jeopardize the CBFM goals. What leads to conflicts in such contexts is that elites often focus on the revenue they generate whereas for the local poor, the priority is income for subsistence. Ribot et al. (2010) also alluded to this problem and called for a balanced approach to achieve sustainability at the landscape level.

\section{Monitoring and reporting}

Monitoring and reporting were also found to be very weak in all the case study countries. The reporting formats, reporting details, and reporting frequencies were not explicit for any of the countries. This indicates that forests under such management models could be subjected to any form of misuse that could go unnoticed except during the inspection or checks by the forestry authorities. Only Tanzania and Uganda describe the types of indicators that need to be monitored to understand how the community is managing the forest. In Ethiopia, although there were no clearly stated indicators at the policy and strategy levels, some management agreements reviewed contained some explicit indicators. Nonetheless, stating the indicators alone may not be that effective for proper forest management unless there is a diligent process of monitoring those indicators as per the required standards. All the countries, however, did mention the types of activities that could be conducted in the forest.

If there are no proper monitoring and reporting procedures, the chance that CBFM schemes fall into the trap of elite capture is quite high. From the start, communities have very high expectations (Koech et al. 2009), thinking that once the community groups are formed (e.g., CFAs), they will have access to most of the forest products including timber. And they also think that the members have a preferential access to use the forestland for the priority uses they want. These are not possible because such actions would lead to unsustainable resource exploitation. To avoid such disappointments, communities should be informed about their rights and responsibilities through the forestry officials during the CBFM development process in a bid to have clear rules of engagement. Unless the activities taking place in the forest are monitored periodically and reported transparently, forest loss, hence a negative outcome, is inevitable.

\section{Product management}

This is among the weakest attributes in all the case study countries. There was no explicit marketing and value addition strategy described by any of the countries. However, there are growing arguments that the benefit communities generate from NTFPs could increase if market access is granted (Gelo et al. 2016) and if value addition opportunities are designed and supported properly. There is also a wide disparity between what the community expects to exploit from the forest under CBFM schemes and what they actually get (Koech et al. 2009). In Kenya and Ethiopia, community benefits are limited to NTFPs. In Cameroon, communities are allowed to exploit timber but only based on agreed annual exploitation rates. In Tanzania, communities are allowed to harvest timber and other forest products as long as they do not exploit them improperly.

\section{Examining contributions of community based forest management (CBFMs) to selected sustainable development goals (SDGs)}

\section{Community based forest management and poverty reduction} (SDG 1)

There is considerable appraisal about contributions of CBFM schemes to various attributes of poverty reduction. For instance, in Ethiopia, after the introduction of PFM in the Bonga forest, the mean annual household income of member households increased from ETB 1589 (Ethiopian Birr; equivalent to US\$71 at current rate) to ETB 2433 (Gobeze et al. 2009). A similar report from the same country showed that annual income grew by about ETB 400 (Gelo et al. 2016). Community based forest managements were also proven to improve welfare (Kellert et al. 2000, Gelo et al. 2013). In Cameroon, Oyono et al. (2012) reported an increase in income of above 5000 folds in selected CFs. In the Iringa district in Tanzania, the average annual village level income from CBFM forests was about US\$653 (Topp-Jørgensen et al. 2005). Table 3 summarizes the impacts of CBFMs on poverty alleviation and livelihood related impacts.

Some study countries did not have a positive contribution to SDG 1 with their CBFM initiative. For instance, recent analysis conducted in Tanzania proved that JFM schemes do not have any clear impact on household income and forest-derived income (Persha and Meshack 2016). However, the authors highlighted that the forests under consideration were not solely community controlled. The other concern in Tanzania, as highlighted by Meschak et al. (2006), is that the poor are the ones who bear the large cost of forest management activities while the major beneficiaries of the schemes are the upper wealthy class of the community. This was also reported in Ethiopia, Uganda, and Kenya (Gelo et al. 2013, Chomba et al. 2015a). For instance, in 
Table 3. Summary of impacts of community based forest management (CBFM) schemes on poverty alleviation/income/livelihood in sub-Saharan Africa. Note: NTFP = nontimber forest products.

\begin{tabular}{|c|c|c|c|c|}
\hline Source & Country & Type of CBFM & $\begin{array}{l}\text { Nature of } \\
\text { impact }\end{array}$ & $\begin{array}{l}\text { (Quantified) Impact on income, poverty alleviation, } \\
\text { livelihood }\end{array}$ \\
\hline Topp-Jørgensen et al. (2005) & Tanzania & $\begin{array}{l}\text { Participatory forest } \\
\text { management }\end{array}$ & Positive & $\begin{array}{l}\text { "... average annual village incomes of US } \$ 653 \text { per year from } \\
\text { CBFM forests." }\end{array}$ \\
\hline Topp-Jørgensen et al. (2005) & Tanzania & Joint forest management & Positive & $\begin{array}{l}\text { "Average annual village incomes US\$ } 189 \text { from JFM areas } \\
\text { inside national forest reserves." }\end{array}$ \\
\hline Oyono (2005) & Cameroon & Community forest & Positive & $\begin{array}{l}\text { " } \ldots \text { in the Kongo village, ... U.S. } \$ 29,730 \text { generated by the } \\
\text { community forest from December } 2001 \text { to December } 2003 . "\end{array}$ \\
\hline Blessings et al. (2006) & Malawi & Comanagement & Positive & $\begin{array}{l}\text { "...program participation raises forest income by between } 47 \\
\text { and } 51 \% \text {." }\end{array}$ \\
\hline Mamo et al. (2007) & Ethiopia & $\begin{array}{l}\text { Participatory forest } \\
\text { management }\end{array}$ & Positive & $\begin{array}{l}\text { "...forest income contributed } 39 \% \text { of the average household } \\
\text { income." }\end{array}$ \\
\hline Yemiru et al. (2010) & Ethiopia & $\begin{array}{l}\text { Participatory forest } \\
\text { management }\end{array}$ & Positive & $\begin{array}{l}\text { "...forest products are the most important sources of } \\
\text { income contributing to } 34 \% \text { and } 53 \% \text { of household per } \\
\text { capita income and per capita cash income, respectively." }\end{array}$ \\
\hline Kamanga et al. (2009) & Malawi & $\begin{array}{l}\text { Community forest } \\
\text { reserves }\end{array}$ & Positive & "Forest income constitutes around $15 \%$ of total income." \\
\hline Gelo and Koch (2014) & Ethiopia & Joint forest management & Positive & $\begin{array}{l}\text { "...the result implies that decentralization policies of this } \\
\text { nature (JFM with market access) can provide alternative } \\
\text { avenues of raising rural income, thereby promoting rural } \\
\text { development." }\end{array}$ \\
\hline Gobeze et al. (2009) & Ethiopia & $\begin{array}{l}\text { Participatory forest } \\
\text { management }\end{array}$ & Positive & $\begin{array}{l}\text { "Participatory forest management helped to diversify } \\
\text { income sources, increase household income level, and build } \\
\text { household assets." }\end{array}$ \\
\hline Gbedomon et al. (2016) & Benin & CBFM & Positive & $\begin{array}{l}\text { "The approach (CBFM) ... yielded positive economic } \\
\text { outcomes that enabled bordering populations to make up to } \\
25 \% \text { of their global annual income from the forest." }\end{array}$ \\
\hline Ambrose-Oji (2003) & Cameroon & Community forests & Positive & "NTFPs may make up to $15 \%$ of the household income." \\
\hline Gatiso and Wossen (2015) & Ethiopia & $\begin{array}{l}\text { Participatory forest } \\
\text { management }\end{array}$ & Positive & $\begin{array}{l}\text { "The community forest contributes } 38.2 \% \text { of the total } \\
\text { annual income of the households in the study area." }\end{array}$ \\
\hline Njana et al. (2013) & Tanzania & Joint forest management & Positive & $\begin{array}{l}\text { "...Miombo woodlands of Urumwa Forest Reserve account } \\
\text { for } 42 \% \text { of total household income." }\end{array}$ \\
\hline Fonta and Ayuk (2013) & Nigeria & Community forests & Positive & $\begin{array}{l}\text { "...it (forest income) accounts for over } 53 \% \text { of average } \\
\text { household income for the poor while for the average and the } \\
\text { rich, it contributes about } 36 \% \text { and } 21 \% \text { of their respective } \\
\text { income shares." }\end{array}$ \\
\hline Matiku et al. (2013) & Kenya & PFM & Positive & $\begin{array}{l}\text { The annual income generated from the PFM forest is about } \\
44516 \text { Kenyan Shilling. }\end{array}$ \\
\hline Vyamana (2009) & Tanzania & $\begin{array}{l}\text { Participatory forest } \\
\text { management }\end{array}$ & Positive & $\begin{array}{l}\text { "Household incomes from PFM forests generally increased } \\
\text { slightly..." }\end{array}$ \\
\hline $\begin{array}{l}\text { Beauchamp and Ingram } \\
\text { (2011) }\end{array}$ & Cameroon & Community forests & Positive & $\begin{array}{l}\text { "CFs...resulted in net benefits that enhance rural livelihoods } \\
\text {... compared to a situation without a community forest." }\end{array}$ \\
\hline Persha and Meshack (2016) & Tanzania & Joint forest management & No impact & $\begin{array}{l}\text { "...no evidence of an impact (positive or negative) of JFM } \\
\text { on livelihoods, but there are weak indications of } \\
\text { improvements in subsistence forest product harvesting." }\end{array}$ \\
\hline Senganimalunje et al. (2016) & Malawi & $\begin{array}{l}\text { Participatory forest } \\
\text { management }\end{array}$ & No impact & $\begin{array}{l}\text { "The results have shown that PFM has not resulted in the } \\
\text { expected outcomes in utilization of forest products and } \\
\text { livelihoods." }\end{array}$ \\
\hline Mazunda and Shively (2015) & Malawi & $\begin{array}{l}\text { Co-Management of } \\
\text { forests }\end{array}$ & No impact & $\begin{array}{l}\text { "We also find that the program had no discernible impact } \\
\text { on household forest incomes, suggesting that the program } \\
\text { helped achieve environmental goals without compromising } \\
\text { household livelihoods." }\end{array}$ \\
\hline $\begin{array}{l}\text { Schreckenberg and Luttreil } \\
\text { (2009) }\end{array}$ & Tanzania & $\begin{array}{l}\text { Participatory forest } \\
\text { management }\end{array}$ & No impact & $\begin{array}{l}\text { "The overall contribution of forest products to household } \\
\text { income in the Tanzanian PFM case study communities did } \\
\text { not change markedly with the introduction of PFM." }\end{array}$ \\
\hline Oyono et al. (2012) & Cameroon & Community forests & No change & $\begin{array}{l}\text { "By and large, the allocation of new community rights to } \\
\text { forests is not leading to the presence/improvement of these } \\
\text { basic assets at the household level in all the research areas." }\end{array}$ \\
\hline
\end{tabular}

The documents in this table are those that show quantitative or qualitative impact of CBFM schemes on income, poverty reduction, and livelihood improvement from the total of 44 publications selected for the analysis. The publications are ordered by nature of impact (positive, no change, negative). 
Uganda, Budongo Forest Reserve, the annual income shares from forests for the rich households increased by about US\$162 while that of the lowest income quartile groups decreased by US\$15 per year (Jagger 2008). In some instances, the CBFM schemes are operating at a loss, hence having negative impacts on poverty reduction. For example, Mogoi et al. (2012), based on evidence from a long-term study on 11 community forest associations (CFAs) in Kenya, found that $21 \%$ of the CFAs could not even meet their expenses for forest management interventions. Hence, implying a fifth of Kenya's CFAs could not even invest in community development activities because they were already running in losses.

Community based forest management and food security (SDG 2) Though evidence on the contribution of CBFM to food security is scant, emerging statistics show that it decreases vulnerability to food insecurity (Meshack et al. 2006, Gobeze et al 2009). It also helps to increase food production by about $66.7 \%$ (Meshack et al. 2006) because of increased access to inputs and better farmland management. In Ethiopia, after PFM was introduced, the income contribution from crop and livestock production increased to 30.9 and $13.5 \%$, respectively (Gobeze et al. 2009). With improvement in household income, communities can easily access food from the market. Besides, if benefits from CBFM schemes are invested in community infrastructure such as roads and transportation, construction of food storage cold rooms, etc., it reduces exposure to food insecurity.

However, there are concerns that improved forest management may result in better habitat conditions for vermin (e.g., apes, monkeys, rodents, etc.), which move into the nearby farms and damage crops. This affects food production, hence diminishing household level food security (Meshack et al. 2006). The strong focus of CBFM schemes on forest conservation is undermining the attention given to food security for the engaged households. Though not yet supported by empirical evidence, the diversion of work force to forest conservation through CBFM schemes may decrease the work force available for food production hence worsened food security risk (Woteva community forest management in Cameroon, personal communication).

\section{Community based forest management and healthy living (SDG 3)}

Community based forest management improves healthy living by increasing access to and investments in health facilities and benefits. Evidence from Nepal, for instance, indicated significant investment in health services (Bhattarai 2011). Traditional medicines extracted from forests are also key sources of medication in many African countries (Mahomoodally 2013). Improved management of CBFMs increases access to this source of medicines hence improving health benefits.

\section{Community based forest management and climate change (SDG} 13)

The CBFMs are believed to have a very promising potential for addressing climate change. Especially with REDD+ moving into its implementation phase in many countries like Cameroon. Conserving forests has become so crucial. The main aim of CBFM adoption was to reduce deforestation and forest degradation. The aims embedded in CBFM provide a crucial pathway to achieve the REDD+ objectives (Agrawal and Angelson 2009). There is strong potential to reduce emissions due to deforestation and forest degradation while managing the sequestration of the carbon stock in the conserved forest ecosystems. In Tanzania, a few REDD+ pilots were already established in CBFM schemes (see Mustalahti et al. 2012). Despite the motivation to engage in REDD+ through CBFM, the extent to which REDD+ benefits could be attractive compared to other forgone opportunities remains a question. This is especially the case given the significant decline in the carbon prices on the voluntary market lately compared to the values proposed at the early stages of discussion on the REDD+ agenda. There is also concern from the CBFM schemes that poverty reduction, which is among the primary aims for engaging the local community in CBFM, often becomes a secondary target for other stakeholders such as the government and conservation agencies.

\section{Community based forest management and forest conservation} (SDG 15)

Though there is a strong consensus on the positive contributions of CBFMs to forest conservation relative to the state-controlled management models, the impacts are often place based and context specific. A similar analysis conducted by Ribot et al. (2010) also highlights the mixed reports of impacts of CBFM on forest conservation. In Ethiopia, the adoption of PFM decreased the pressure on forests for forest products extraction and conversion to other farming activities (Lemenh and Bekele 2008, Takahashi and Todo 2012). Takahashi and Todo (2012) found that, on average, forests under CBFM increased by $1.5 \%$ in the first two years whereas forests in areas outside CBFM shrank by about 3.3\%. In Tanzania, because of CBFM, there is strong improvement in protection and management of VLFRs (Kajembe et al. 2002, Blomley et al. 2008, Persha and Meshack 2016). Meshack et al. (2006) also reported increases in forest regeneration/cover by $95 \%$ and increases in trees on private farms by $89.2 \%$.

On the other hand, there were also areas in Tanzania (e.g., coastal regions) in which deforestation worsened even after adopting CBFM, possibly due to other factors such as market influences (Brockington 2007, Blomley et al. 2008). Persha and Meshack (2016) also reported that JFM has no significant impact on deforestation and forest degradation in Tanzania. In Cameroon, Bruggeman et al. (2015) found that there is no major difference in the rate of deforestation between $\mathrm{CF}$ areas and other land-use zones. In Kenya, Kellert et al. (2000) highlighted that CBFM schemes increased the pressure to exploit natural resources by unduly fueling expectations and increasing access. Similar intentions of exploitation were also reported in Cameroon as a result of CBFM schemes (Oyono 2005). Table 4 provides the summary of impacts from various literature.

In principle, the above two different reports of CBFM schemes' impacts on forest conservation call for a consistent methodology of impact monitoring (i.e., what needs to be measured, how should it be measured, what baseline should be used, and how should the interpretation of impacts be conducted) under different contexts. This should be developed and supported by technical experts working with CBFM and validated in different contexts. The CBFMs do have various impacts on SDG targets. The impact pathways are not always the same. Table 5 summarizes the main pathways through which CBFMs influence selected SDGs. 
Table 4. Summary of impacts of community based forest management (CBFM) schemes on forest management in sub-Saharan Africa.

\begin{tabular}{|c|c|c|c|c|}
\hline Source & Country & Type of CBFM & $\begin{array}{l}\text { Nature of } \\
\text { impact }\end{array}$ & Description of impact on forest management \\
\hline $\begin{array}{l}\text { Blomley and Ramadhani } \\
\text { (2006) }\end{array}$ & Tanzania & $\begin{array}{l}\text { Participatory forest } \\
\text { management and joint } \\
\text { forest management }\end{array}$ & Positive & $\begin{array}{l}\text { "PFM does indeed contribute to sustainable forest } \\
\text { management whether under CBFM arrangements on village } \\
\text { land, or under JFM arrangements in reserved land." }\end{array}$ \\
\hline Newton et al. 2015 & Tanzania & $\begin{array}{l}\text { Community forest } \\
\text { management }\end{array}$ & Positive & $\begin{array}{l}\text { "REDD+ funding is being used to expand the area of forest } \\
\text { under Participatory Forest Management." }\end{array}$ \\
\hline Mazunda and Shively 2015 & Malawi & Comanagement & Positive & $\begin{array}{l}\text { "...the program lowered the rate and extent of forest } \\
\text { clearing." }\end{array}$ \\
\hline Ameha et al. (2016) & Ethiopia & $\begin{array}{l}\text { Participatory forest } \\
\text { management }\end{array}$ & Positive & $\begin{array}{l}\text { "The overall densities of mature trees ha }{ }^{-1} \text { and four } \\
\text { individual species (Afrocarpus falcatus, Schefflera } \\
\text { abyssinica, Hypericum lanceolatum, and Rapanea } \\
\text { melanophloeos) were higher in forests under participatory } \\
\text { management }(p<0.01) . "\end{array}$ \\
\hline Takahashi and Todo (2012) & Ethiopia & $\begin{array}{l}\text { Participatory forest } \\
\text { management }\end{array}$ & Positive & $\begin{array}{l}\text { "On average, the forest area of the forest associations } \\
\text { increased by } 1.5 \% \text { in the first } 2 \text { years, whereas forest areas } \\
\text { not managed as part of an association declined by } 3.3 \% \text {." }\end{array}$ \\
\hline Tadesse et al. (2016) & Ethiopia & $\begin{array}{l}\text { Participatory forest } \\
\text { management }\end{array}$ & Positive & $\begin{array}{l}\text { "PFM had a positive effect on forest conditions. Species } \\
\text { diversity and evenness were higher in the forest with PFM } \\
\left(\mathrm{H}^{\prime}=3.29, \mathrm{E}=.85\right) \text { compared to the forest without PFM } \\
\left(\mathrm{H}^{\prime}=2.97, \mathrm{E}=.79\right) \text {. The overall mean values of tree/shrub } \\
\text { and seedling density per hectare, diameter class }(\leq 20 \mathrm{~cm}) \\
\text { were also significantly }(p<.05) \text { higher in PFM forest than } \\
\text { non-PFM forests." }\end{array}$ \\
\hline Blomley et al. (2008) & Tanzania & $\begin{array}{l}\text { Participatory forest } \\
\text { management }\end{array}$ & Positive & $\begin{array}{l}\text { "We conclude that participatory forest management is } \\
\text { showing signs of delivering impact in terms of improved } \\
\text { forest condition in Tanzanian forests." "... we demonstrate } \\
\text { increasing basal area and volume of trees per ha over time } \\
\text { in Miombo woodland and coastal forest habitats under } \\
\text { participatory forest management compared with similar } \\
\text { forests under state or open access management." }\end{array}$ \\
\hline Gobeze et al. (2009) & Ethiopia & $\begin{array}{l}\text { Participatory forest } \\
\text { management }\end{array}$ & Positive & $\begin{array}{l}\text { "PFM is shown to have positive impacts both on the state } \\
\text { of the forest .... at least within the project life time. Forest } \\
\text { conditions such as seedling and sapling densities improved." }\end{array}$ \\
\hline Mbwambo et al. (2012) & Tanzania & $\begin{array}{l}\text { Joint forest management } \\
\text { and CBFM }\end{array}$ & Positive & $\begin{array}{l}\text { "...some empirical evidence indicating that JFM and CBFM } \\
\text { performed better than the ordinary state management, } \\
\text { although uncontrolled exploitation of the forest has } \\
\text { continued under decentralised forest management." }\end{array}$ \\
\hline Sauer and Abdallah (2007) & Tanzania & Village land forest reserve & Positive & $\begin{array}{l}\text { "Family forests showed a lower volume and basal area } \\
\left(11.14 \mathrm{~m}^{3} \mathrm{ha}^{-1} \text { and } 2.52 \mathrm{~m}^{2} \mathrm{ha}^{-1} \text {, respectively) compared to }\right. \\
\text { the forest reserves }\left(20.01 \mathrm{~m}^{3} \mathrm{ha}^{-1} \text { and } 4.25 \mathrm{~m}^{2} \mathrm{ha}^{-1} \text {, }\right. \\
\text { respectively)." The forest reserves referred to are VLFR. }\end{array}$ \\
\hline $\begin{array}{l}\text { Beauchamp and Ingram } \\
\text { (2011) }\end{array}$ & Cameroon & Community forests & Positive & $\begin{array}{l}\text { "CFs...resulted in net benefits that enhance rural livelihoods } \\
\text { and sustainable management of natural resources, } \\
\text { compared to a situation without a community forest." }\end{array}$ \\
\hline Persha and Meshack (2016) & Tanzania & Joint forest management & No impact & $\begin{array}{l}\text { "We found no significant difference in deforestation rates } \\
\text { between JFM and non-JFM forest reserves during } \\
\text { 2000-2012." }\end{array}$ \\
\hline Oyono (2005) & Cameroon & Community forests & Negative & $\begin{array}{l}\text { "...negative environmental results, such as the degradation } \\
\text { of many community forests in the forested Cameroon" }\end{array}$ \\
\hline Oyono et al. (2012) & Cameroon & Community forests & Negative & $\begin{array}{l}\text { "...the transfer of new rights to the local communities is, for } \\
\text { the time being, leading to observable and advanced } \\
\text { overexploitation in the Lomié/Dja and Ocean areas." }\end{array}$ \\
\hline
\end{tabular}

\section{DISCUSSION AND CONCLUSION}

Despite efforts to implement CBFM in Africa over the last two decades, our analysis reveals several weaknesses in the CBFM frameworks that limit the realization of objectives behind the CBFM establishment, i.e., conserving forests, improving livelihoods, and granting communities rights over resources. Our results justify the often criticized aspect of CBFM, that it did not genuinely grant communities forest management rights. The proof is that almost all the case study countries had policies and legislative provisions in place, but implementation of the prescribed provisions is very limited and weak. For instance, access to forest products (i.e., exploitation rights) and tenure conditions were still vaguely formulated in all the countries. The other major policy limitation is, in countries like Ethiopia and 
Table 5. Selected impact pathways linking community based forest management (CBFM) with sustainable development goals (SDGs).

\begin{tabular}{lll}
\hline \hline SDG & Identified impact pathways & Detailed description \\
\hline SDG 1 - Poverty reduction & Forest income & $\begin{array}{l}\text { This includes income generated from sale of timber and } \\
\text { nontimber forest products such as fuelwood, wild fruits, } \\
\text { medicinal plants, etc. }\end{array}$
\end{tabular}

Nonforest income resulting from forest management

Income from activities packaged with CBFMs

Income through governance arrangements

Forest foods, wood, and energy

SDG 2 - Food security

Improved access to food

Forests serving as food safety nets

SDG 3 - Healthy lives

Investment in community health infrastructure
SDG 13 - Climate change Contributions to carbon sequestration

Adaptation benefits

REDD+ benefits

SDG 15 - Forest and biodiversity Improved forest management conservation
Reduced rate of forest encroachment for agriculture

Enhanced engagement in forest management activities

Better habitats for wildlife
Reports of improved assets possession by CBFM participants such as tv, radio, motorbikes, wells, etc.

This includes revenues generated through fees for research by visiting scientists, tourist entry fees, etc.

Participatory forest management in the study countries come with various activities such as apiculture (honey), goat and sheep rearing, butterfly farming, casual labor, etc.

Incentives, e.g., tax waiver in Tanzania increasing the net income of communities; Revenues from fines from trespassers to be used by the CBFM members.

People collect wild foods (e.g., fruits, bush meat, mushrooms, etc.); People collect fuelwood from forests.

Using the income generated from the CBFM schemes, communities access food on the market.

This involves edible items directly harvested from forests. Investments in district hospital by subsidizing hospital bills, financing clinics, establishing and financing dispensaries, paying nurses and birth attendants and, supporting awareness creation and educational programmes on HIV AIDS and maternal health. Herbal medicines often are collected from forests.

Improving forest management translates better biomass and soil carbon sequestration.

Improved forest conditions means better forest foods, energy, and other benefits at time of shocks due to food shortage, etc. CBFM, at varying degrees, reduce the rate of deforestation and forest degradation which are the principal objectives of REDD+. Besides, enhanced conservation of forests through CBFM contributes to the objectives of REDD+.

Rates of deforestation and forest degradation decreases with CBFM schemes.

Because the community patrols and protects the forest, clearance of forest lands for unplanned agricultural activities decreases.

Member communities were reported to be engaged in tree planting, forest patrolling, etc., which improved forest status. Forest in all the study countries are critical habitats for wildlife. Improving forest management means better biodiversity conservation.
Kenya, that CBFM is not a mainstream management approach yet but rather sort of projects with short time frames. That is why many CBFM schemes in the two countries still largely depend on NGO support, on top of being supported by the national and subnational governments, as one of the mainstream management approaches with clear budget and plans.

Reluctance by the state to unleash power over resources to local communities (Ribot et al. 2006) is a key challenge. This reluctance is largely not because of the concern that forests could be destroyed, but because the state loses commercial value or revenues (Oyono 2005, Mogoi et al 2012, Chomba et al. 2015b). As a result, CBFMs happen on poor quality forest that generate limited benefits for communities because good quality forests remain under state custody. Anderson et al. (2015) argued that CBFM is like letting the communities manage the leftovers, i.e., poor quality forests yielding limited benefits but with high transaction cost of management. Even under such a situation, Chomba et al. (2015b) in Kenya argued that communities do not have full control over revenues generated from CBFM because of strong interference and involvement by the government, hence less benefits to the community. Mutune et al. (2017) also argued that PFM or CBFM did not give communities the decisionmaking power over high-value forest products such as timber and firewood and hence if PFM has to succeed in its objectives, there is a need for further devolution of rights.

Compared to the state-controlled management models, CBFMs improved the rights and ownership of resources and hence contributed to local resource governance by communities in SSA (Kajembe et al. 2002, Lemenh and Bekele 2008, Ongugo et al. 2008, Mustalahti et al. 2012, Persha and Meshack 2016). 
However, these rights are sometimes unduly apportioned within particular groups and sectors in local communities (Kellert et al. 2000, Chomba et al. 2015a). This misappropriation of rights, as argued by Chomba et al. (2015a), increases the vulnerability of marginalized members in the community. This is how both local elites (e.g., village leaders, local chiefs, etc.) and or external elites (e.g., rich, educated and powerful individuals from urban and government institutions) emerge and deprive local communities of the benefits from forests. Elite capture issues were strongly emphasized in Ethiopia (Gelo et al. 2013), Cameroon (Oyono 2006), and Kenya (Kellert et al. 2000, Mogoi et al. 2012, Chomba et al. 2015a). Ezzine de Blas et al. (2011) also reported that because of poor governance and lack of transparency, the CF scheme in Cameroon fell short of significantly contributing to improving livelihoods among target communities. This limited transparency and accountability led to limited investment of returns from the forests on collective community benefits and services. The major limitation of the current CBFM framing is that it fails to recognize diversity within a group or an association. It largely focuses on intrastakeholders' issues rather than interstakeholder matters. Even when (democratic) elections were conducted to elect management committees, CBFMs were often susceptible to within-group elite capture problems. Reports of CBFM schemes largely benefiting the rich more than the poor are very frequent in the case study countries.

Gelo et al. (2016) specifically stated that market linkage is fundamental to enhance CBFM's contributions to poverty alleviation, food security, and community well-being. In all the study countries, product management was observed to be one of the weakest and less explicitly stated CBFM framework attributes. As a result, even when communities have products to sell, due to lack of market access they do not benefit properly. Hence, often they sell the products cheaply to middlemen and women who make significant profit out of their efforts. Value addition could be one of the main means of enhancing contributions of CBFM schemes to poverty alleviation and well-being improvement. However, as also reported by Koech et al. (2009), communities often have limited financial capacity to kick-start such enterprises that may enhance CBFM contributions.

Overall, because of numerous limitations in the current CBFM frameworks, evidence of contributions of the scheme to local development and forest management were quite mixed, with numerous cases of positive but marginal contributions. This agrees quite well with the Ribot et al. (2010) and the Arts and de Koning (2017) findings. The observed major weaknesses in the CBFM frameworks could be addressed by doing an appropriate procedures audit to devise appropriate CBFM frameworks that facilitate the adoption of the scheme as a mainstream management approach. This, however, should not be misinterpreted because there is no one common framework that can best fit into the diverse settings within which CBFMs are implemented. Although the elements of the framework attributes could be similar, the minimum requirements for each framework attribute may need to be the same. This is in line with Agrawal and Chhatre (2006) who also argued that factors affecting CBFM performance operate differently in different contexts and hence it may be difficult to have a universal approach.

Improving $\mathrm{CBFM}$ scheme contributions to SDGs requires a thorough look into the framework attributes of CBFMs. Key areas of emphasis should be: (1) strategies for enhancing transparency and accountability, (2) establishment of market linkages, (3) value addition strategies for products extracted from the forests, and (4) mechanisms for a fair and equitable reward for community members engaged in CBFM. Among the common critiques of CBFM is that it (intentionally or unintentionally) prioritizes forest management over community development needs (Meshack et al 2006, Koech et al. 2009, Ribot et al. 2010). In fact, Charnley and Poe (2007) observed this bias to forest conservation in the Americas too. The call for a balanced approach to meet the objectives that prioritize forest management and community development needs is growing and is also crucial to present CBFM as a viable alternative forest management model.

Based on findings from our study and others, the following are important measures that may help improve CBFMs implementation and contribution to the objectives behind its creation:

- Capacity building (Koech et al. 2009, Baynes et al. 2015) for communities particularly on forest ecosystem management and product management;

- Improving the types of forests that should be allocated to communities while also noting the biodiversity and climate impact implications of such allocations;

- Designing a fair share of responsibility in conserving forests between communities and government and/or state agencies;

- Empowering local communities to make some critical decisions relating to the management of forests (Mutune et al. 2017);

- Allowing access to startup capital for successful community enterprise development; and

- Devising strategies to address the intergroup and intragroup complexities (Baynes et al. 2015) to reduce elite capture issues.

Responses to this article can be read online at: http://www.ecologyandsociety.org/issues/responses. $\mathrm{php} / 10514$

\section{Acknowledgments:}

This paper is produced as part of the outputs for the project Financing Sustainable Community Forest Enterprises in Cameroon. We are grateful for the support of the UK Aid Department for International Development for this project. We are very grateful to Elizabeth Kahurani Kimani for the intensive language editing.

\section{LITERATURE CITED}

Agrawal, A., and A. Angelsen. 2009. Using community forest management to achieve REDD+ goals. Pages 201-212 in A. Angelsen, M. Brockhaus, M. Kanninen, E. Sills, W. D. Sunderlin, and S. Wertz-Kanounnikoff, editors. Realising REDD+: national strategy and policy options. Center for International Forestry 
Research, Bogor, Indonesia. [online] URL: http://www.cifor.org/ publications/pdf_files/Books/BAngelsen090216.pdf

Agrawal, A., and A. Chhatre. 2006. Explaining success on the commons: community forest governance in the Indian Himalaya. World Development 34(1):149-166. http://dx.doi.org/10.1016/j. worlddev.2005.07.013

Agrawal, A., and C. C. Gibson. 1999. Enchantment and disenchantment: the role of community in natural resource conservation. World Development 27(4):629-649. http://dx.doi. org/10.1016/S0305-750X(98)00161-2

Agrawal, A., and J. Ribot. 1999. Accountability in decentralization: a framework with South Asian and West African cases. Journal of Developing Areas 33(4):473-502.

Alemagi, D. 2010. A comparative assessment of community forest models in Cameroon and British Columbia, Canada. Land Use Policy 27(3):928-936. http://dx.doi.org/10.1016/j.landusepol.2009.12.006

Ambrose-Oji, B. 2003. The contribution of NTFPs to the livelihoods of the 'forest poor': evidence from the tropical forest zone of south-west Cameroon. International Forestry Review 5 (2):106-117. http://dx.doi.org/10.1505/IFOR.5.2.106.17420

Ameha, A., H. Meilby, and G. L. Feyisa. 2016. Impacts of participatory forest management on species composition and forest structure in Ethiopia. International Journal of Biodiversity Science, Ecosystem Services and Management 12:139-153. http:// dx.doi.org/10.1080/21513732.2015.1112305

Anderson, J. 2000. Four considerations for decentralized forest management: subsidiarity, empowerment, pluralism and social capital. Food and Agriculture Organization of the United Nations, Rome, Italy. [online] URL: http://www.fao.org/ docrep/003/x6898e/x6898e02a.htm

Anderson, J., S. Mehta, E. Epelu, and B. Cohen. 2015. Managing leftovers: does community forestry increase secure and equitable access to valuable resources for the rural poor?. Forest Policy and Economics 58:47-55. http://dx.doi.org/10.1016/j.forpol.2014.12.004

Arts, B., and J. de Koning. 2017. Community forest management: an assessment and explanation of its performance through QCA. World Development 96:315-325. https://doi.org/10.1016/j. worlddev.2017.03.014

Ayana, A. N., B. Arts, and K. F. Wiersum. 2013. Historical development of forest policy in Ethiopia: trends of institutionalization and deinstitutionalization. Land Use Policy 32:186-196. http://dx.doi.org/10.1016/j.landusepol.2012.10.008

Ayana, A. N., N. Vandenabeele, and B. Arts. 2017. Performance of participatory forest management in Ethiopia: institutional arrangement versus local practices. Critical Policy Studies 1:19-38. http://dx.doi.org/10.1080/19460171.2015.1024703

Baynes, J., J. Herbohn, C. Smith, R. Fisher, and D. Bray. 2015. Key factors which influence the success of community forestry in developing countries. Global Environmental Change 35:226-238. http://dx.doi.org/10.1016/j.gloenvcha.2015.09.011

Beauchamp, E., and V. Ingram. 2011. Impacts of community forests on livelihoods in Cameroon: lessons from two case studies. International Forestry Review 13:389-403. http://dx.doi. org/10.1505/146554811798811371
Bhattarai, R. C. 2011. Economic impact of community forestry in Nepal: a case of mid-hill districts of Nepal. Economic Journal of Development Issues 13-14:75-96. http://dx.doi.org/10.3126/ ejdi.v13i0.7212

Blessings, C., L. Jumbe, and A. Angelsen. 2006. Do the poor benefit from devolution policies? Evidence from Malawi's forest co-management program. Land Economics 82(4):562-581. http:// dx.doi.org/10.3368/le.82.4.562

Blomley, T. 2013. Lessons learned from community forestry in Africa and their relevance for REDD+. USAID-supported Forest Carbon, Markets and Communities (FCMC) Program, Washington, D.C., USA. [online] URL: https://www.climatelinks. org/sites/default/files/asset/document/CF_Africa.pdf

Blomley, T., and H. Ramadhani. 2006. Going to scale with participatory forest management: early lessons from Tanzania. International Forestry Review 8(1):93-100. http://dx.doi. org/10.1505/ifor.8.1.93

Blomley, T., K. Pfliegner, J. Isango, E. Zahabu, A. Ahrends, and N. Burgess. 2008. Seeing the wood for the trees: an assessment of the impact of participatory forest management on forest condition in Tanzania. Oryx 42(03):380-391. http://dx.doi. org/10.1017/S0030605308071433

Brockington, D. 2007. Forests, community conservation, and local government performance: the village forest reserves of Tanzania. Society and Natural Resources 20(9):835-848. http://dx. doi.org/10.1080/08941920701460366

Bruggeman, D., P. Meyfroidt, and E. F. Lambin. 2015. Production forests as a conservation tool: effectiveness of Cameroon's land use zoning policy. Land Use Policy 42:151-164. http://dx.doi. org/10.1016/j.landusepol.2014.07.012

Bwalya, S. M. 2002. Critical analysis of community-based wildlife resource management in Southern Africa: case study from Zambia. Pages in Commons in an age of globalisation, the biennial ninth conference of the International Association for the Study of Common Property, Victoria Falls, Zimbabwe. International Association for the Study of Common Property, Bloomington, Indiana, USA.

Charnley, S., and M. R. Poe. 2007. Community forestry in theory and practice: where are we now?. Annual Review of Anthropology 36:301-336. http://dx.doi.org/10.1146/annurev.anthro.35.081705.123143

Chomba, S. W., I. Nathan, P. A. Minang and F. Sinclair. $2015 a$. Illusions of empowerment? Questioning policy and practice of community forestry in Kenya. Ecology and Society 20(3):2. http:// dx.doi.org/10.5751/ES-07741-200302

Chomba, S., T. Treue, and F. Sinclair. 2015b. The political economy of forest entitlements: can community based forest management reduce vulnerability at the forest margin? Forest Policy and Economics 58:37-46. http://dx.doi.org/10.1016/j. forpol.2014.11.011

DeGrassi, A. 2003. Constructing subsidiarity, consolidating hegemony: political economy and agro-ecological processes in Ghanaian forestry. World Resources Institute, Washington, D.C., USA. 
Enters, T., and J. Anderson. 1999. Rethinking the decentralization and devolution of biodiversity conservation. Unasylva 50(4). [online] URL: http://www.fao.org/docrep/x3030e/x3030e04.htm

Ezzine de Blas, D., M. Ruiz-Pérez, and C. Vermeulen. 2011. Management conflicts in Cameroonian community forests. Ecology and Society 16(1):8. http://dx.doi.org/10.5751/ES-03845-160108

Fonta, W. M., and E. T. Ayuk. 2013. Measuring the role of forest income in mitigating poverty and inequality: evidence from southeastern Nigeria. Forests, Trees and Livelihoods 22(2):86-105. http://dx.doi.org/10.1080/14728028.2013.785783

Gatiso, T. T, and T. Wossen. 2015. Forest dependence and income inequality in rural Ethiopia: evidence from Chilimo-Gaji community forest-users. International Journal of Sustainable Development and World Ecology 22(1):14-24. http://dx.doi. org/10.1080/13504509.2014.946543

Gbedomon, R. C., A. Floquet, R. Mongbo, V. K. Salako, A. B. Fandohan, A. E. Assogbadjo, and R. G. Kakaii. 2016. Socioeconomic and ecological outcomes of community based forest management: a case study from Tobé-Kpobidon forest in Benin, Western Africa. Forest Policy and Economics 64:46-55. http://dx. doi.org/10.1016/j.forpol.2016.01.001

Gelo, D., and S. F. Koch. 2014. The impact of common property right forestry: evidence from Ethiopian villages. World Development 64:395-406. http://dx.doi.org/10.1016/j.worlddev.2014.06.020

Gelo, D., S. F. Koch, and E. Muchapondwa. 2013. Do the poor benefit from devolution policies? Evidences from quantile treatment effect evaluation of joint forest management. Economic Research Southern Africa (ERSA) Working Paper 400. Economic Research Southern Africa, Cape Town, South Africa. [online] URL: https:// econrsa.org/system/files/publications/working_papers/working_paper_400. pdf

Gelo, D., E. Muchapondwa, and S. F. Koch. 2016. Decentralization, market integration and efficiency-equity tradeoffs: evidence from joint forest management in Ethiopian villages. Journal of Forest Economics 22:1-23. http://dx.doi.org/10.1016/j. ife.2015.10.003

Gobeze, T., M. Bekele, M. Lemenih, and H. Kassa. 2009. Participatory forest management and its impacts on livelihoods and forest status: the case of Bonga forest in Ethiopia. International Forestry Review 11(3):346-358. http://dx.doi. org/10.1505/ifor.11.3.346

Jagger, P. 2008. Forest incomes after Uganda's forest sector reform: are the rural poor gaining? CAPRi working paper No. 92. International Food Policy Research Institute, Washington, D.C., USA. [online] URL: http://ebrary.ifpri.org/utils/getfile/collection/ p15738coll2/id/22543/filename/22544.pdf

Kajembe, G. C., G. C. Monela, and Z. S. Mvena. 2002. Making community-based forest management work: a case study from Duru-Haitemba village forest reserve, Babati, Arusha, the United Republic of Tanzania. Pages 18-22 in Second international workshop on participatory forestry in Africa. Defining the way forward: sustainable livelihoods and sustainable forest management through participatory forestry. FAO, Rome, Italy. [online] URL: http://www.fao.org/docrep/pdf/006/Y4807B/Y4807B15.pdf
Kamanga, P., P. Vedeld, and E. Sjaastad. 2009. Forest incomes and rural livelihoods in Chiradzulu District, Malawi. Ecological Economics 68:613-624. http://dx.doi.org/10.1016/j.ecolecon.2008.08.018

Kellert, S. R., J. N. Mehta, S. A. Ebbin, and L. L. Lichtenfeld. 2000. Community natural resource management: promise, rhetoric, and reality. Society and Natural Resources 13(8):705-715. http://dx.doi.org/10.1080/089419200750035575

Kenya Forest Service. 2015. Participatory forest management guidelines. Kenya Forest Service, Nairobi, Kenya. [online] URL: http://www.kenyaforestservice.org/documents/pfm/PFM $\% 20$ Guilines $\%$ 20Final $\% 202016$.pdf

Klooster, D., and O. Masera. 2000. Community forest management in Mexico: carbon mitigation and biodiversity conservation through rural development. Global Environmental Change 10:259-272 http://dx.doi.org/10.1016/S0959-3780(00) $\underline{00033-9}$

Koech, C. K., P. O. Ongugo, M. T. E. Mbuvi, and J. O. Maua. 2009. Community forest associations in Kenya: challenges and opportunities. Kenya Forestry Research Institute, Nairobi, Kenya. [online] URL: https://www.fornis.net/sites/default/files/documents/ Community $\% 20$ Forest $\% 20$ Associations $\% 20$ in $\% 20$ Kenya $\% 20$ challenges $\%$ 20and\%20oppo-205 0.pdf

Larson, A. M. 2003. Decentralisation and forest management in Latin America: towards a working model. Public Administration and Development 23(3):211-226. http://dx.doi.org/10.1002/ $\underline{\operatorname{pad}} 271$

Larson, A. M. 2005. Democratic decentralization in the forestry sector: lessons learned from Africa, Asia and Latin America. Pages 32-62 in C. J. Pierce Colfer and D. Capistrano, editors. The politics of decentralization: forests, power and people. Earthscan, London, UK.

Lemenh, M., and T. Bekele. 2008. Participatory forest management: best practices, lesson learnt and challenges encountered: the Ethiopian and Tanzanian experiences. FARMAfrica/SOS-Sahel, Nairobi, Kenya. [online] URL: https:// theredddesk.org/sites/default/files/resources/pdf/PFM $\% 201$ essons $\%$ 2C $\% 20$ challenges $\% 20$ and $\% 20$ best $\% 20$ practices.pdf

Mahomoodally, M. F. 2013. Traditional medicines in Africa: an appraisal of ten potent African medicinal plants. Evidence-based Complementary and Alternative Medicine 2013:617459. http://dx. doi.org/10.1155/2013/617459

Mamo, G., E. Sjaastad, and P. Vedeld. 2007. Economic dependence on forest resources: a case from Dendi District, Ethiopia. Forest Policy and Economics 9:916-927. http://dx.doi. org/10.1016/j.forpol.2006.08.001

Matiku, P., M. Caleb, and O. Callistus. 2013. The impact of participatory forest management on local community livelihoods in the Arabuko-Sokoke forest, Kenya. Conservation and Society 11(2):112-129 http://dx.doi.org/10.4103/0972-4923.115724

Mazunda, J., and G. Shively. 2015. Measuring the forest and income impacts of forest user group participation under Malawi's forest co-management program. Ecological Economics 119:262-273. http://dx.doi.org/10.1016/j.ecolecon.2015.09.016 
Mbwambo, L., T. Eid, R. E. Malimbwi, E. Zahabu, G. C. Kajembe, and E. Luoga. 2012. Impact of decentralised forest management on forest resource conditions in Tanzania. Forests, Trees and Livelihoods 21(2):97-113. http://dx.doi. org/10.1080/14728028.2012.698583

Meshack, C. K., B. Ahdikari, N. Doggart, and J. C. Lovett. 2006. Transaction costs of community governance beyond the local scale. African Journal of Ecology 44(4):468-477. http://dx.doi. org/10.1111/j.1365-2028.2006.00659.x

Minang, P. A., H. T. A. Bressers, M. M. Skutsch, and M. K. McCall. 2007a. National forest policy as a platform for biosphere carbon management: the case of community forestry in Cameroon. Environmental Science and Policy 10(3):204-218. http://dx.doi.org/10.1016/j.envsci.2007.01.007

Minang, P. A., L. A. Duguma, F. Bernard, D. Foundjem-Tita, and Z. Tchoundjeu. 2018. Evolution of community forestry in Cameroon: an innovation ecosystems perspective. Ecology and Society XX(YY):ZZ

Minang, P. A., M. K. McCall, and H. T. A. Bressers. $2007 b$. Community capacity for implementing clean development mechanism projects within community forests in Cameroon. Environmental Management 39(5):615-630. http://dx.doi.org/10.1007/ $\underline{\mathrm{s} 00267-005-0275-2}$

Ministry of Environment, Forest and Climate Change (MEFCC). 2017. Ethiopia forest sector review focus on commercial forestry and industrialization. Technical report for the Federal Democratic Republic of Ethiopia, Ministry of Environment, Forest and Climate Change and the World Bank, Addis Ababa, Ethiopia. [online] URL: http://mefcc.gov.et/ethiopia-forest-sector-review/

Ministry of Water and Environment (MWE). 2016. State of Uganda's forestry 2015. Department for International Development, Kampala, Uganda, and Food and Agriculture Organization for the United Nations, Rome, Italy. [online] URL: http://www.mwe.go.ug/sites/default/files/State $\% 20$ of $\% 20$ Uganda $\%$ $27 \mathrm{~s} \% 20$ Forestry-2015.pdf

Mogoi, J., E. Obonyo, P. Ongugo, V. Oeba, and E. Mwangi. 2012. Communities, property rights and forest decentralisation in Kenya: early lessons from participatory forestry management. Conservation and Society 10(2):182-194. http://dx.doi. org/10.4103/0972-4923.97490

Movuh, M. C. Y. 2013. Analyzing the establishment of community forestry $(\mathrm{CF})$ and its processes examples from the south west region of Cameroon. Journal of Sustainable Development 6(1):76. http://dx.doi.org/10.5539/jsd.v6n1p76

Mustalahti, I., A. Bolin, E. Boyd, and J. Paavola. 2012. Can REDD+ reconcile local priorities and needs with global mitigation benefits? Lessons from Angai Forest, Tanzania. Ecology and Society 17(1):16. http://dx.doi.org/10.5751/ ES-04498-170116

Mutune, J. M., C. P. Hansen, R. G. Wahome, and D. N. Mungai. 2017. What rights and benefits? The implementation of participatory forest management in Kenya: the case of Eastern Mau Forest Reserve. Journal of Sustainable Forestry 36 (3):230-249. http://dx.doi.org/10.1080/10549811.2017.1289105
Ndegwa, S. N. 2002. Decentralization in Africa: a stocktaking survey. World Bank, Washington, D.C., USA. [online] URL: https://pdfs.semanticscholar.org/3b66/f927bc94ed7afd697b58dd194768aac08d4b.pdf? ga $=2.33060282 .545246516 .1538244795-2-$ $\underline{39086269.1538244795}$

Newton, P., B. Schaap, M. Fournier, M. Cornwall, D. W. Rosenbach, J. DeBoer, J. Whittemore, R. Stock, M. Yoders, G. Brodnig, and A. Agrawal. 2015. Community forest management and REDD +. Forest Policy and Economics 56:27-37. http://dx. doi.org/10.1016/j.forpol.2015.03.008

Njana, M. A., G. C. Kajembe, and R. E. Malimbwi. 2013. Are miombo woodlands vital to livelihoods of rural households? Evidence from Urumwa and surrounding communities, Tabora, Tanzania. Forests, Trees and Livelihoods 22(2):124-140. http://dx. doi.org/10.1080/14728028.2013.803774

Olowu, D. and United Nations Research Institute for Social Development. 2001. Decentralization policies and practices under structural adjustment and democratization in Africa. United Nations Research Institute for Social Development, Geneva, Switzerland.

Ongugo, P. O., J. N. Mogoi, E. Obonyo, and V. O. Oeba. 2008. Examining the roles of community forest associations (CFAS) in the decentralization process of Kenyan forests. A conference paper presented at IASC Conference 11th-19th July 2008 England. [online] URL: http://citeseerx.ist.psu.edu/viewdoc/download?

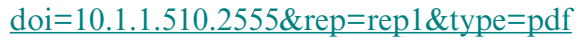

Oyono, P. R. 2005. Profiling local-level outcomes of environmental decentralizations: The case of Cameroon's forests in the Congo Basin. Journal of Environment and Development 14 (3):317-337. http://dx.doi.org/10.1177/1070496505276552

Oyono, P. R. 2006. Acteurs locaux, représentation et "politics" des co-pouvoirs dans le Cameroun rural post-1994. Canadian Journal of Development Studies/Revue canadienne d'études du $\tilde{d} \tilde{A} \mathrm{C}$ veloppement 27(2):163-185.

Oyono P. R., M. B. Biyong, and S. K. Samba. 2012. Beyond the decade of policy and community euphoria: the state of livelihoods under new local rights to forest in rural Cameroon. Conservation and Society 10(2):173-181. http://dx.doi.org/10.4103/0972-4923.97489

Persha, L., and C. Meshack. 2016. A triple win? The impact of Tanzania's Joint Forest Management programme on livelihoods, governance and forests. Impact Evaluation Report 34. International Initiative for Impact Evaluation, New Delhi, India. [online] URL: http://www.3ieimpact.org/media/filer_public/2016/03/30/ ie34-tanzania-joint-forest.pdf http://dx.doi.org/10.23846/ow31109

Ribot, J. C. 1999. Decentralisation, participation and accountability in Sahelian forestry: legal instruments of politicaladministrative control. Africa 69(1):23-65. http://dx.doi. org/10.2307/1161076

Ribot, J. C. 2003. Democratic decentralisation of natural resources: institutional choice and discretionary power transfers in sub-Saharan Africa. Public Administration and Development 23 (1):53-65. http://dx.doi.org/10.1002/pad.259

Ribot, J. C., A. Agrawal, and A. M. Larson. 2006. Recentralizing while decentralizing: how national governments reappropriate 
forest resources. World Development 34(11):1864-1886. http://dx. doi.org/10.1016/j.worlddev.2005.11.020

Ribot, J. C., J. F. Lund, and T. Treue. 2010. Democratic decentralization in sub-Saharan Africa: its contribution to forest management, livelihoods, and enfranchisement. Environmental Conservation 37(1):35-44. http://dx.doi.org/10.1017/S0376892910000329

Robinson, E. J. Z., and R. B. Lokina. 2011. A spatial-temporal analysis of the impact of access restrictions on forest landscapes and household welfare in Tanzania. Forest Policy and Economics 13(1):79-85. http://dx.doi.org/10.1016/j.forpol.2010.08.003

Roe, D., F. Nelson, and C. Sandbrook. 2009. Community management of natural resources in Africa: impacts, experiences and future directions. International Institute for Environment and Development, London, UK. [online] URL: http://pubs.iied.org/ pdfs/17503IIED.pdf

Sarin, M., N. M. Singh, N. Sundar, and R. K. Bhogal. 2003. Devolution as a threat to democratic decision-making in forestry? Findings from three states in India. Overseas Development Institute, London, UK. [online] URL: https://www.odi.org/sites/ odi.org.uk/files/odi-assets/publications-opinion-files/2436.pdf

Sauer, J., and J. M. Abdallah. 2007. Forest diversity, tobacco production and resource management in Tanzania. Forest Policy and Economics 9(5):421-439. http://dx.doi.org/10.1016/j. forpol.2005.10.007

Scheba, A., and I. Mustalahti. 2015. Rethinking 'expert' knowledge in community forest management in Tanzania. Forest Policy and Economics 60:7-18. http://dx.doi.org/10.1016/j. forpol.2014.12.007

Schreckenberg, K., and C. Luttrell. 2009. Participatory forest management: a route to poverty reduction? International Forestry Review 11(2):221-238 http://dx.doi.org/10.1505/ifor.11.2.221

Senganimalunje, T. C., P. W. Chirwa, F. D. Babalola, and M. A. Graham. 2016. Does participatory forest management program lead to efficient forest resource use and improved rural livelihoods? Experiences from Mua-Livulezi Forest Reserve, Malawi. Agroforestry Systems 90:691-710. http://dx.doi. org/10.1007/s10457-015-9826-6

Smith, J., and S. J. Scherr. 2002. Forest carbon and local livelihoods: assessment of opportunities and policy recommendations. CIFOR Occasional Paper no. 37. Center for International Forestry Research, Jakarta, Indonesia. [online] URL: http://www.cifor. org/publications/pdf files/OccPapers/OP-037.pdf

Tadesse, S. A., and D. Teketay. 2017. Perceptions and attitudes of local people towards participatory forest management in Tarmaber District of North Shewa Administrative Zone, Ethiopia: the case of Wof-Washa forests. Ecological Processes 6 (1):17. http://dx.doi.org/10.1186/s13717-017-0084-6

Tadesse, S., M. Woldetsadik, and F. Senbeta. 2016. Impacts of participatory forest management on forest conditions: evidences from Gebradima Forest, southwest Ethiopia. Journal of Sustainable Forestry 35(8):604-622. http://dx.doi. org/10.1080/10549811.2016.1236279

Takahashi, R., and Y. Todo. 2012. Impact of community-based forest management on forest protection: evidence from an aid- funded project in Ethiopia. Environmental Management 50 (3):396-404. http://dx.doi.org/10.1007/s00267-012-9887-5

Topp-Jørgensen, E., M. K. Poulsen, J. F. Lund, and J. F. Massao. 2005. Community-based monitoring of natural resource use and forest quality in montane forests and miombo woodlands of Tanzania. Biodiversity and Conservation 14(11):2653-2677. http:// dx.doi.org/10.1007/s10531-005-8399-5

United Republic of Tanzania (URT). 2011. Annual review of the general budget support 24th-25th November 2011. Final report. Ministry of Natural Resources and Tourism, Dar es Salaam, Tanzania. [online] URL: http://www.tzdpg.or.tz/fileadmin/ migrated/content uploads/GBS AR Report 2011 Final 01.pdf

Vyamana, V. G. 2009. Participatory forest management in the Eastern Arc Mountains of Tanzania: who benefits? International Forestry Review 11(2):239-253. http://dx.doi.org/10.1505/ifor.11.2.239

Yami, M., W. Mekuria, and M. Hauser. 2013. The effectiveness of village bylaws in sustainable management of communitymanaged exclosures in Northern Ethiopia. Sustainability Science 8(1):73-86. http://dx.doi.org/10.1007/s11625-012-0176-2

Yemiru, T., A. Roos, B. M. Campbell, and F. Bohlin. 2010. Forest incomes and poverty alleviation under participatory forest management in the Bale Highlands, Southern Ethiopia. International Forestry Review 12(1):66-77. http://dx.doi. org/10.1505/ifor.12.1.66 